\title{
Effect of non-surgical periodontal treatment on glycemic control of patients with diabetes: a meta-analysis of randomized controlled trials

Quan $\mathrm{Li}^{1}$, Sha Hao ${ }^{2,3}$, Jie Fang ${ }^{1}$, Jing Xie ${ }^{4}$, Xiang-Hui Kong ${ }^{5}$ and Jian-Xin Yang ${ }^{1 *}$

\begin{abstract}
Objective: The present study aimed at investigating whether non-surgical periodontal treatment can reduce the Haemoglobin A1c (HbA1c) \% level in type 2 diabetic patients.

Methods: A search of the literature on English publications was performed in Cochrane Central, Medline, ISI Web of Knowledge and EMBASE (until 06 February 2014). An RCT was selected if the subject was type 2 diabetic patients diagnosed with chronic periodontitis, and compared $\mathrm{HbA} 1 \mathrm{c} \%$ change after non-surgical periodontal treatment alone for at least three months of the study duration. Weighted mean difference for pooled data and large sample size strata were calculated. Heterogeneity and publication bias were explored.

Results: After the study selection process, only 9 RCTs were suitable. Compared to the control group, the pooled analysis ( $n=1082$ ) showed $-0.27 \%$ (95 \% Cl:-0.46 \% to $-0.07 \%, p=0.007$ ) absolute difference in HbA1c \% with treatment while studies with sufficient sample size had HbA1c \% change of $-0.014 \%$ (95\% Cl:-0.18 \% to $0.16 \%$, $p=0.87$ ). Publication bias was marginally significant with Egger's teat $(p=0.045)$ but not with Begg's test $(p=0.72)$.

Conclusion: The moderate reduction in HbA1c after the non-surgical therapy in patients with type 2 diabetes is consistent with previous systematic reviews. However, more large scale and high-quality RCTs are necessitated to confirm these results.
\end{abstract}

Keywords: Chronic periodontitis, HbA1c, Diabetes mellitus type 2, Dental scaling, Root planning

\section{Introduction}

Recently the relationship between diabetes mellitus and chronic periodontitis has attracted the attention of researchers worldwide. Many studies suggested a two-way relationship between diabetes mellitus and chronic periodontitis [1-5]. Poor glycemic control can induce the increased risk of periodontal disease or of its greater severity in patients with diabetes. Accordingly, DM2 (type 2 diabetes mellitus) is considered as one of the risk factors of periodontal disease [6, 7]. Enhanced glycemic control can alleviate the pathological progress of the periodontal disease $[8,9]$.

Periodontitis is diagnosed when there is gingival inflammation, periodontal ligament and alveolar bone loss,

\footnotetext{
*Correspondence: yangjx13@163.com

${ }^{1}$ Center of Stomatology, the Second Affiliated Hospital of Soochow

University, No.1055 Sanxiang Road, Soochow 215004, P. R. China

Full list of author information is available at the end of the article
}

and apical migration of junctional epithelium [10, 11]. Clinical manifestations include increased probing pocket depth or clinical attachment loss. Therapies for periodontitis are composed of oral hygiene instruction, scaling, root planing, antibiotics, chlorhexidine, surgical treatment, or a combination of these [12].

The DM2 is regarded nowadays as a worldwide epidemic. According to the WHO(World Health Organization) the global upcoming estimative of the number of people with DM2 will reach 366 million in the year 2030 [13]. DM2 (a metabolic disease resulting from defects in insulin production, insulin activity, or both) can cause microand macrovascular complications. Glycemic control is crucial in preventing complications [14-17]. HbA1c represents serum glucose levels during the 120-day life of the red blood cell, and is a robust indicant of glycemic control [18]. 
Some previous meta-analyses observed a significant positive effect of non-surgical periodontal treatment on glycemic control despite lack of homogeneity and robustness among studies [19-22]. Since then, some new randomized controlled trials have been done. Therefore, it is time to provide an update to accumulate more evidence and evaluate the potential effect of non-surgical periodontal treatment on glycemic control.

\section{Review}

\section{Methods}

\section{Search stratege}

Four databases (Cochrane CENTRAL, ISI Web of Science, MEDLINE (via PubMed) and EMBASE) have been systematically searched using the search terms [see Additional file 1], from their inception to 01 April 2015. Moreover, a manual search was performed from the last 20 years of the following journals: Journal of Periodontology, Journal of Dental Research, Journal of Clinical Periodontology, Journal of Periodontal Research, Journal of Dentistry, Journal of the American Dental Association, Periodontology 2000, Journal of Clinical Dentistry, Clinical Oral Investigations, Clinical
Diabetes, Diabetologia, Diabetes, Diabetes Care, and Diabetes Research and Clinical Practice. To be as comprehensive as possible, the reference lists of the searched publications were thoroughly cross-checked to avoid omission of relevant studies.

\section{Study selection criteria}

The following inclusion criteria had to be met: (1) randomized controlled clinical trial (RCT); (2) population: type 2 diabetes mellitus diagnosed with periodontitis; (3) non-surgical periodontal treatment without adjunctive use of local drug delivery and systemic antibiotics at least 3 months of follow-up; (4) control group with no periodontal treatment or delayed treatment; (5) outcome: mean change in HbA1c level; and(6) only published studies in the English language were considered for inclusion.

The Cochrane Handbook for Systematic Reviews of Interventions (Version 5.1.0) was used as a guideline for the selection process [23]. All retrieved articles were evaluated by four independent reviewers (QL, HS, JF and JXY). Disagreements were resolved by consensus. Figure 1 showed the reasons for exclusion. Since the

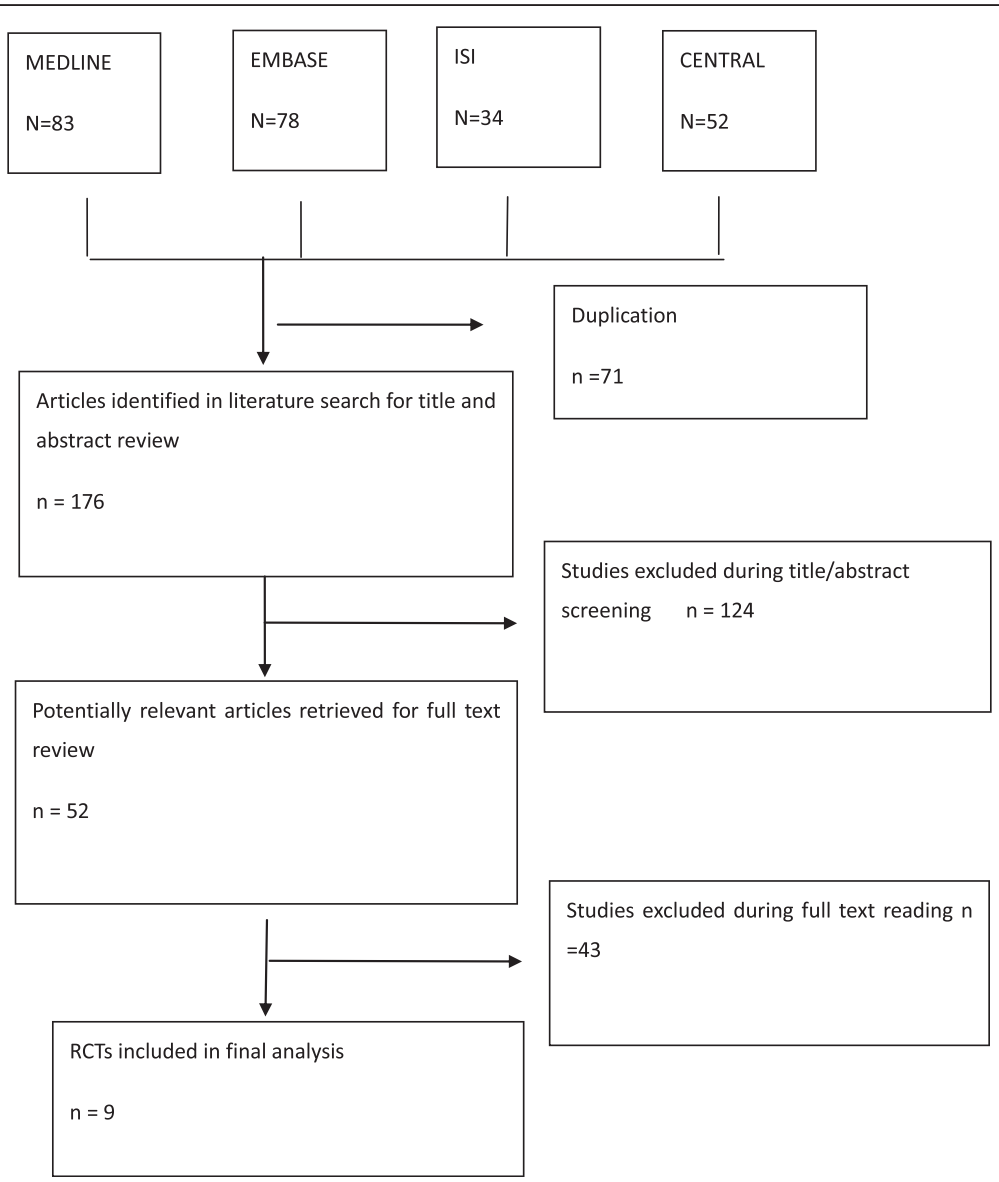

Fig. 1 Flow Chart for the systematic review and meta-analysis 
databases were not mutually exclusive, reduplicative entries were removed.

After excluding articles ineligible for the study, the relevance of all articles were screened from the titles and abstracts. Full-text articles were assessed while articles which did not meet the pre-specified inclusion criteria were excluded.

\section{Methodological study quality assessment}

Study quality was evaluated independently by two authors (HS and JF) with the following parameters, which were: (1) random sequence generation; (2) allocation concealment; (3) incomplete data outcome; (4) blinding; and (5) intention-to-treat analysis, as previously described [20].

\section{Data extraction}

Four authors (QL, HS, JF and JXY) independently extracted data from each RCT in pre-designed forms. Any disagreements were resolved by consensus. From all relevant studies, the key parameters including demographics of the population, study quality, intervention in the control and treatment groups, follow-up duration and design, mean change of HbA1c levels in both groups were recorded. When not reported, the absolute difference of HbA1c level was calculated by extracting the mean change of HbA1c in the control group and the mean change of HbA1c in the intervention group. Standard deviation of the mean change of HbAlc level from baseline to follow-up was calculated according to a method previously described [24].

\section{Statistical analysis}

All data for meta-analysis were submitted to STATA 12.0(Texas, USA). A meta-analysis was conducted, comparing the intervention group with non-surgical periodontal treatment and the control group which received no periodontal treatment or delayed treatment.

For a particular multi-arm study, the treatment group fulfilling the selection criteria for pair-wise comparison were included [23]. Thus, only the intervention group and control group contrasting non-surgical periodontal treatment alone versus no treatment/delayed treatment will be used for data analysis.

Weighted mean difference was calculated using a random effect model (Dersimonian-Laird method) from the included RCTs. In addition, the significant heterogeneity was assessed by chi-square test for homogeneity (Cochran Q-statistic and P-value), as well as I-squared statistic and $95 \% \mathrm{CI}$ of the $\mathrm{I}^{2}$. Publication bias was estimated by Begg's test, Egger's test and funnel plot.

\section{Results}

The initial search from the four databases retrieved 247 articles, after removal of duplicates. The titles and abstracts of these studies were evaluated for inclusion, and the reasons for exclusion are showed in Fig. 1. Of these articles, only 52 articles were identified for fulltext reading. Finally, a total of 9 RCTs were considered for the meta-analysis. No additional studies were identified by cross-checking the bibliographies of relevant and retrieved articles.

\section{Study characteristics}

The characteristics of the 9 RCTs are listed in Table 1. All studies included were randomized controlled trials [25-33].The The mean age of subjects in the included studies ranged from 52.8 to 62.7 years. All selected studies are of subjects having both DM2 and chronic periodontitis. Scaling and root planning/curettage/debridement were regarded as the basic non-surgical periodontal treatment for the intervention group in all studies. In Singh et al., group B $(\mathrm{n}=15)$ was excluded for the meta-analysis because the adjunctive systemic doxycycline (100 mg daily for 14 days) was administrated [29].

\section{Methodological study quality assessment}

Risk of bias was assessed for each selected study by the following parameters, which are: random sequence generation, allocation concealment, blinding of participants and personnel, incomplete data outcome and intentionto-treat analysis. (Table 2). Only Engebretson et al. and Koromantzos et al. reported implementing intention-totreat analysis [27, 31]. Allocation concealment was not observed in 3 studies [25-27].

\section{Pooled analysis}

A statistically significant difference in HbAlc reduction was seen in the pooled analysis (Fig. 2) between the intervention and control groups $(\mathrm{p}=0.007)$, with an effect size of $-0.27 \%$ (95 \% CI:- $0.46 \%$ to $-0.07 \%$ ).

\section{Exploration of heterogeneity}

The heterogeneity $\left(\mathrm{I}^{2}\right)$ among the 9 studies was $41.7 \%$ $\left(\mathrm{X}^{2}=15.43, \mathrm{p}=0.080\right)$, which suggested moderate heterogeneity.

Since sample size was identified as a potential source of heterogeneity, then subgroup analysis was conducted. Non-surgical periodontal intervention with small sample size $(\mathrm{n}<80)$ showed a significant improvement $(\mathrm{p}=0.005)$ of HbA1c level [-0.46 \% (95 \% CI:-0.79 \% to $-0.14 \%$ )]. Also, the heterogeneity among studies was moderate $\left(\mathrm{x}^{2}=9.64, \mathrm{p}=0.086, \mathrm{I}^{2}=48.2 \%\right)(25,27-30)$. However, this improvement was not significant $(\mathrm{p}=0.65)$ with large sample size trials, with HbA1c \% change of $0.01 \%$ (95\% CI:- $0.18 \%$ to $0.16 \%, \mathrm{p}=0.87$ ) [26, 31, 32]. 
Table 1 The characteristics of the included studies

\begin{tabular}{|c|c|c|c|c|c|c|c|c|c|c|c|c|c|c|c|}
\hline \multirow[t]{3}{*}{ Study } & \multirow[t]{3}{*}{ Year } & \multirow[t]{3}{*}{ Country } & \multirow{2}{*}{\multicolumn{4}{|c|}{ Number(n) }} & \multirow[t]{3}{*}{ Interventions } & \multirow{2}{*}{\multicolumn{3}{|c|}{$\begin{array}{l}\text { Mean age years(SD) } \\
\text { Male } \%\end{array}$}} & \multirow{2}{*}{\multicolumn{3}{|c|}{$\begin{array}{l}\text { Mean baseline } \\
\mathrm{HbA1c} \%(\mathrm{SD})\end{array}$}} & \multirow{3}{*}{$\begin{array}{l}\text { Follow-up } \\
\text { time(months) }\end{array}$} & \multirow{3}{*}{$\begin{array}{l}\text { Study design } \\
\text { and detail }\end{array}$} \\
\hline & & & & & & & & & & & & & & & \\
\hline & & & Total & C & $T \times 1$ & $T \times 2$ & & $\mathrm{C}$ & $T \times 1$ & $T \times 2$ & $C$ & $T \times 1$ & $T \times 2$ & & \\
\hline \multirow[t]{2}{*}{ Kiran et al. } & \multirow[t]{2}{*}{2005} & \multirow[t]{2}{*}{ Turkey } & \multirow[t]{2}{*}{44} & \multirow[t]{2}{*}{22} & \multirow[t]{2}{*}{22} & & \multirow{2}{*}{$\begin{array}{l}\text { Control: delayed } \\
\text { treatment TX1: oral } \\
\text { hygiene+SRP }\end{array}$} & \multirow[t]{2}{*}{$\begin{array}{l}52.82(12.27) \\
36\end{array}$} & \multirow[t]{2}{*}{$\begin{array}{l}55.95(11.21) \\
45\end{array}$} & & \multirow[t]{2}{*}{$7.0(0.72)$} & \multirow[t]{2}{*}{$\begin{array}{l}7.31 \\
(0.74)\end{array}$} & & \multirow[t]{2}{*}{3} & $\begin{array}{l}\text { RCT Single } \\
\text { centre }\end{array}$ \\
\hline & & & & & & & & & & & & & & & $\begin{array}{l}\text { Blinding of } \\
\text { assessor }\end{array}$ \\
\hline Chen et al. & 2012 & China & 134 & 44 & 45 & 45 & $\begin{array}{l}\text { Control: no treatment } \\
\text { Tx1: SRP Tx2: } \\
\text { supragingival } \\
\text { prophylaxis }\end{array}$ & $\begin{array}{l}63.2(8.51) \\
41.5\end{array}$ & $\begin{array}{l}59.86(9.48) \\
54.8\end{array}$ & $\begin{array}{l}57.91(11.35) \\
60.5\end{array}$ & $\begin{array}{l}7.25 \\
(1.49)\end{array}$ & $\begin{array}{l}7.31 \\
(1.23)\end{array}$ & $7.29(1.55)$ & 6 & $\begin{array}{l}\text { RCT Single } \\
\text { centre }\end{array}$ \\
\hline \multirow[t]{2}{*}{$\begin{array}{l}\text { Koromantzos } \\
\text { et al. }\end{array}$} & \multirow[t]{2}{*}{2012} & \multirow[t]{2}{*}{ Greece } & \multirow[t]{2}{*}{60} & \multirow[t]{2}{*}{30} & \multirow[t]{2}{*}{30} & & \multirow{2}{*}{$\begin{array}{l}\text { Control:supragingival } \\
\text { cleaning Tx:SRP in } \\
\text { two sessions }\end{array}$} & \multirow[t]{2}{*}{$59.42(9.8) 56.7$} & \multirow[t]{2}{*}{$59.62(7.95) 53.3$} & & \multirow[t]{2}{*}{$7.59(0.66)$} & \multirow{2}{*}{\multicolumn{2}{|c|}{$7.87(0.74)$}} & \multirow[t]{2}{*}{$\begin{array}{l}3 \text { and } 6 \\
\text { months }\end{array}$} & $\begin{array}{l}\text { RCT Single } \\
\text { centre }\end{array}$ \\
\hline & & & & & & & & & & & & & & & $\begin{array}{l}\text { Blinding of } \\
\text { assessor }\end{array}$ \\
\hline $\begin{array}{l}\text { Moeintaghavi } \\
\text { et al. }\end{array}$ & 2012 & Iran & 40 & 18 & 22 & & $\begin{array}{l}\text { Control: delayed } \\
\text { treatment TX1: SRP }\end{array}$ & $53.5(9.51) 61.1$ & $\begin{array}{l}56.27(10.52) \\
40.9\end{array}$ & Overall 50.29(3) & $\begin{array}{l}8.72 \\
(2.22)\end{array}$ & $\begin{array}{l}8.15 \\
(1.18)\end{array}$ & & 3 & $\begin{array}{l}\text { RCT Single } \\
\text { centre Blinding } \\
\text { of assessor }\end{array}$ \\
\hline Singh et al. & 2008 & India & 45 & 15 & 15 & 15 & $\begin{array}{l}\text { Control:no treatment } \\
\text { Tx1:SRP Tx2: SRP } \\
\text { +systemic } \\
\text { doxycycline }\end{array}$ & $59.3(10.8) 56.3$ & $52.8(10.36) 48.8$ & & $8.08(0.78)$ & 7.93(0.78) & $8.33(0.72)$ & 3 & $\begin{array}{l}\text { RCT Single } \\
\text { centre }\end{array}$ \\
\hline Zhang et al. & 2013 & China & 71 & 22 & 49 & & $\begin{array}{l}\text { Control:no treatment } \\
\text { TX:SRP }\end{array}$ & $62.7(10.7) 42.9$ & $60.4(9.77) 45.5$ & & $7.38(1.30)$ & $7.68(1.22)$ & & $\begin{array}{l}3 \text { and } 6 \\
\text { months }\end{array}$ & $\begin{array}{l}\text { RCT Single } \\
\text { centre Blinding } \\
\text { of assessor }\end{array}$ \\
\hline $\begin{array}{l}\text { Engebretson } \\
\text { et al. }\end{array}$ & 2013 & USA & 514 & 257 & 257 & & $\begin{array}{l}\text { Control:no treatment } \\
\text { Tx:SRP+mouthwash }\end{array}$ & $57.9(9.6) 42.1$ & $56.7(10.5) 45.6$ & & $7.78(0.60)$ & $7.84(0.65)$ & & $\begin{array}{l}3 \text { and } 6 \\
\text { months }\end{array}$ & $\begin{array}{l}\text { RCT } \\
\text { Multicenter } \\
\text { Blinding of } \\
\text { assessor }\end{array}$ \\
\hline Gay IC et al. & 2014 & USA & 126 & 66 & 60 & & $\begin{array}{l}\text { Control:oral hygiene } \\
\text { instruction Tx1: } \\
\text { scaling +SRP }\end{array}$ & $41.7(10.2) 58.3$ & $45.5(9.0) 54.6$ & & $8.4(2.0)$ & $9.0(2.3)$ & & 3 & $\begin{array}{l}\text { RCT Single } \\
\text { centre }\end{array}$ \\
\hline $\begin{array}{l}\text { Raman } \\
\text { RP et al. }\end{array}$ & 2014 & Malaysia & 32 & 17 & 15 & & $\begin{array}{l}\text { Control:oral hygiene } \\
\text { instruction Tx1: } \\
\text { scaling +SRP }\end{array}$ & 73.3 (9.9) 26.7 & $52.9(6.2) 47.1$ & & $7.6(1.5)$ & $7.8(1.5)$ & & 3 & $\begin{array}{l}\text { RCT Single } \\
\text { centre }\end{array}$ \\
\hline
\end{tabular}


Table 2 Quality measure of included studies in the meta-analysis

\begin{tabular}{|c|c|c|c|c|c|c|}
\hline & $\begin{array}{l}\text { Random sequence } \\
\text { generation }\end{array}$ & $\begin{array}{l}\text { Allocation } \\
\text { concealment }\end{array}$ & $\begin{array}{l}\text { Blinding of participants } \\
\text { and personnal }\end{array}$ & $\begin{array}{l}\text { Incomplete outcome } \\
\text { data addressed }\end{array}$ & $\begin{array}{l}\text { Intention-to-treat } \\
\text { analysis }\end{array}$ & $\begin{array}{l}\text { Selecting } \\
\text { reporting }\end{array}$ \\
\hline Kiran 2005 & $?$ & $?$ & $?$ & + & $?$ & + \\
\hline Chen 2012 & + & $?$ & + & + & - & + \\
\hline $\begin{array}{l}\text { Moeintaghavi } \\
2012\end{array}$ & + & $?$ & $?$ & + & $?$ & + \\
\hline $\begin{array}{l}\text { Koromantzos } \\
2012\end{array}$ & + & + & + & + & + & + \\
\hline Singh 2008 & $?$ & - & + & + & $?$ & + \\
\hline Zhang 2013 & + & + & + & + & - & + \\
\hline $\begin{array}{l}\text { Engebretson } \\
2013\end{array}$ & + & + & + & + & + & + \\
\hline Gay IC 2014 & + & + & + & + & + & + \\
\hline Raman RP 2014 & + & $?$ & $?$ & + & $?$ & + \\
\hline
\end{tabular}

+ adequate, ? unclear, - inadequate

\section{Publication bias}

Visual inspection of the funnel plot revealed an asymmetrical distribution (Fig. 3). In Egger's test, the intercept value of the y-axis was negative $(-2.37)$. The publication bias was marginally significant in Egger's test $(\mathrm{p}=0.045)$, therefore caution should be taken to get the conclusion of no small-study effects. However, Begg's test was not statistically significant $(\mathrm{p}=0.72)$.

\section{Discussion}

This review updates a previous systematic review [19] that was published in 2013, due to an increase of some new large-sample RCTs in this subject. This one contains all previous RCTs [25-29] in that review, and new studies meeting the inclusion criteria have been added. In all, nine randomized clinical trials [25-33] are retrieved, with two new studies [30,31] meet the selection criteria established by Sgolastra et al. [19]. Now the total number of the population of this meta-analysis amount to 1082 , nearly three times the subjects of the metaanalysis by Sgolastra et al. [19]. It is noteworthy that the standard deviation of the $\mathrm{HbA1c}$ reduction ranges in the present analysis from 0.12 to 2.87 , which is consistent with previous reviews [19-22].

\begin{tabular}{|c|c|}
\hline Study & \multirow[t]{2}{*}{ \% Weight } \\
\hline 1 & \\
\hline Moeintaghavi 2012 & 1.59 \\
\hline$\longrightarrow$ & 4.71 \\
\hline 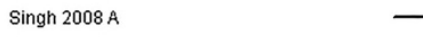 & 6.34 \\
\hline HuiHui Z 2013 AvB & 30.19 \\
\hline Raman RP 2014 & 3.03 \\
\hline Subtotal (1-squared $=48.2 \%, p=0.086)$ & 58.39 \\
\hline . & \\
\hline 2 & \\
\hline Gay IC 2014 & 6.82 \\
\hline Subtotal $(1-$ squared $=0.0 \%, p=0.649$ ) & 41.61 \\
\hline & \\
\hline Overall (l-squared $=41.7 \%, p=0.080$ ) & 100.00 \\
\hline NOTE: Weights are from random effects analysis & \\
\hline $\begin{array}{c} \\
-2.49\end{array}$ & \\
\hline Favours treatment & \\
\hline
\end{tabular}

Fig. 2 Forest plot of comparison: Periodontal Therapy outcome: Change in $\mathrm{HbA1c}(\% \mathrm{HbA} 1 \mathrm{c})$ at 3 months 


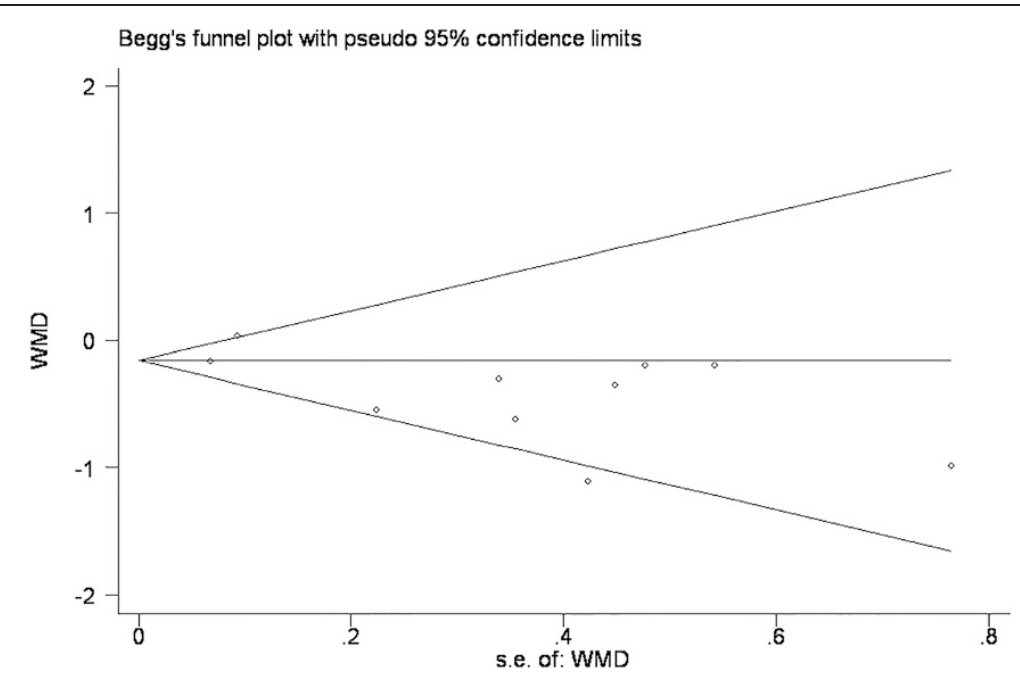

Fig. 3 Funnel plot of comparison: periodontal therapy outcome: change in HbA1c

The moderate effect size of $-0.27 \%$ HbA1c (95 \% CI:$0.46,-0.07)$ observed among all nine studies remains statistically significant, which is consistent with the two recent systematic reviews [-0.36 \% HbA1c,CI:-0.54,-0.19][21] and [-0.65 \% HbA1c, CI:-0.43,-0.88] [19]. Therefore, the present meta-analysis seemingly reaches the conclusion that non-surgical periodontal intervention may reduce the HbA1c level [19]. However, caution should be taken to interpret the data as the heterogeneity among studies was margionally significant $(\mathrm{p}=0.080)$.

When stratified by sample size (Fig. 2), the analysis showed that trials with small sample size $(\mathrm{n}<80)$ demonstrated effective improvement of glycemic control, reducing $0.46 \%$ HbA1c level compared with no treatment $[25,27-30,33]$. The subgroup analysis of small RCTs showed a greater effect size, partially due to the small sample size effect(the small sample size study with larger variance is more likely to overestimate the effect sizes compared with large trials).

Conversely RCTs with large sample size $(n>80)$ showed an insignificant effect size [26, 31, 32]. While recent studies suggested that TNF-a enhanced the insulin resistance in infection by inhibiting insulin-induced tyrosine phosphorylation of insulin receptor substrate-1(IRS-1) [34]. Biological plausibility could be established at this point. Meanwhile only three trials adopted the large sample size within the study design [26, 31, 32]. Therefore, more large-multicenter high-quality RCTs are needed in this area.

Furthermore, the methodological study quality was far from ideal. For instance, per protocol analysis was done in Chen et al. [26], Moeintaghavi et al. [28] and Zhang et al. [30]. This could jeopardize the generation of random sequence. The duration of treatment ranged from three to six months. Although all studies provided mechanical instrumentation as non-surgical periodontal treatment, Engebretson et al. [31] provided chlorhexidine oral rinse at baseline and supportive periodontal therapy at 3 and 6 months. Chen et al. [26] prescribed only supragingival prophylaxis at 3 months in the treatment group 3 with no debridement in deep periodontal pockets. Discrepancies in baseline HbAlc levels, treat regimens of DM2 and the severity of $\mathrm{CP}$ could also account to some extent for the heterogeneity.

The moderate effect size of the reduction of HbA1c $-0.27 \%$ HbA1c (95 \% CI:-0.46,-0.07) was observed among all nine studies. While the clinical value of the HbAbc-reduction can not be neglected. Non-surgical periodontal therapy may be an adjunctive way to enhance glycemic control [34]. It has been suggested that 1 $\%$ reduction in HbA1c levels means 35 \% decrease in complications. It also estimated that a $10 \%$ decrease in mortality is associated with a $0.2 \%$ reduction in $\mathrm{HbA} 1 \mathrm{c}$ [35]. Therefore, despite the modest effect size of the reduction of HbA1c level, non-surgical periodontal treatment regimens enhances the glycemic control.

The precise pathogenesis involving CP and DM2 needs to be further investigated. Chronic periodontitis may initiate or maintain an elevated systemic chronic inflammation. Enhanced serum level of TNF-a, IL-6 and IL-1 can be detected in patients diagnosed with CP and DM2, IL-1 and IL-6 can antagonize the insulin action and TNF-a can interfere with lipid metabolism [36]. Currently several studies have demonstrated that IL-1 antagonism [37-39] and salsalate [40] may get the improved glycemic control of the DM2 with CP.

The strengths of this meta-analysis are the restriction to non-surgical periodontal treatment alone, without the 
adjunctive antibiotics which could interfere the mean change of HbA1c, and the inclusion of the largest multicenter high-quality RCT [31] since the publication of the four reviews in 2013. The outcome suggested that more large sample size and high-quality RCTs are needed to confirm the conclusion.

However, some limitations in the present study should be recognized. The small sample size within the study could lead to the small-study effect. Furthermore, discrepancies in baseline $\mathrm{HbA} 1 \mathrm{c}$ levels, treat regimens of DM2 and CP severity were observed among the included studies.

In order to clarify the biological mechanism of the effect of SRP on the change of HbA1c level, it is important that negative findings in this area should be objectively published.

\section{Conclusion}

The meta-analysis result seems to support the effectiveness of non-surgical periodontal treatment in the enhancement of glycemic control in patients with $\mathrm{CP}$ and DM2. However, more large-multicenter high-quality RCTs are needed to confirm these results.

\section{Additional file}

Additional file 1: Search strategies in Cochrane central, Pubmed, Embase.

\author{
Abbreviations \\ HbA1c: Haemoglobin A1c; DM2: Type 2 diabetes mellitus; WHO: World \\ Health Organization; RCT: Randomized clinical trials; MD: Mean difference; \\ SE: Standard error.
}

\section{Competing interests}

The authors declare that they have no competing interests.

\section{Authors' contributions}

QL conceived the study, participated in the design, collected the data,performed statistical analyses, and drafted the manuscript. SH helped tocollect the data and perform statistical analyses. JF helped to perform statistical analysis and revise the figures. XHK helped to revise the tables and the figures. JX helped to participated in the design and draft the manuscript. JXY conceived the study,participated in the design, and helped to draft the manuscript. All authors read and approved the final manuscript.

\section{Acknowledgements}

The authors would appreciate the reviewers (Steven P Engebretson andLazaros Tsalikis) for their valuable suggestions and questions.

\footnotetext{
Author details

${ }^{1}$ Center of Stomatology, the Second Affiliated Hospital of Soochow University, No.1055 Sanxiang Road, Soochow 215004, P. R. China. ${ }^{2}$ Department of Integrated Chinese and Western Medicine, Union Hospital, Tongji Medical College, Huazhong University of Science and Technology, Wuhan, China. ${ }^{3}$ Department of Medical Oncology, JingmenTraditional Chinese Medicine Hospital, Jingmen 448000, China. ${ }^{4}$ Department of Stomatology, the First Affiliated Hospital of Wenzhou Medical College, No.2 Fuxue Road, Wenzhou, China. ${ }^{5}$ Department of Cardiology, the People's Hospital of Jingmen, Jingmen 448000, China.
}

Received: 27 September 2014 Accepted: 17 June 2015

Published online: 03 July 2015

\section{References}

1. Chee B, Park B, Bartold PM. Periodontitis and type II diabetes: a two-way relationship. Int J Evid Based Healthc. 2013;11:317-29.

2. Gurav AN. Periodontal therapy - an adjuvant for glycemic control. Diabetes Metab Syndr. 2012;6:218-23.

3. Bascones-Martinez A, Arias-Herrera S, Criado-Camara E, Bascones-Ilundain J, Bascones-llundain C. Periodontal disease and diabetes. Adv Exp Med Biol. 2012;771:76-87.

4. Moodley A, Wood NH, Shangase SL. The relationship between periodontitis and diabetes: a brief review. SADJ. 2013;68:260, 262-64.

5. Gurav AN. Advanced glycation end products: a link between periodontitis and diabetes mellitus? Curr Diabetes Rev. 2013;9:355-61.

6. Jimenez M, Hu FB, Marino M, Li Y, Joshipura KJ. Type 2 diabetes mellitus and 20 year incidence of periodontitis and tooth loss. Diabetes Res Clin Pract. 2012;98:494-500

7. Taylor GW, Borgnakke WS. Periodontal disease: associations with diabetes, glycemic control and complications. Oral Dis. 2008;14:191-203.

8. Katagiri S, Nitta H, Nagasawa T, Izumi Y, Kanazawa M, Matsuo A, et al. Effect of glycemic control on periodontitis in type 2 diabetic patients with periodontal disease. J Diabetes Investig. 2013;4:320-5.

9. Goyal L, Gupta ND, Bey A. Periodontal therapy: a useful adjunct to improve glycemic control. J Pharm Bioallied Sci. 2012:4:173-4.

10. Oppermann RV, Weidlich P, Musskopf ML. Periodontal disease and systemic complications. Braz Oral Res. 2012;26 Suppl 1:39-47.

11. Chavarry NG, Vettore MV, Sansone C, Sheiham A. The relationship between diabetes mellitus and destructive periodontal disease: a meta-analysis. Oral Health Prev Dent. 2009;7:107-27.

12. Armitage GC. Periodontal diagnoses and classification of periodontal diseases. Periodontol 2000. 2004;34:9-21.

13. Tibaldi JM. The future of insulin therapy for patients with type 2 diabetes mellitus. J Am Osteopath Assoc. 2013;113:S29-39.

14. Watson KE, Peters Harmel AL, Matson G. Atherosclerosis in type 2 diabetes mellitus: the role of insulin resistance. J Cardiovasc Pharmacol Ther. 2003;8:253-60.

15. Yamaguchi T, Sugimoto T. Bone metabolism and fracture risk in type 2 diabetes mellitus [Review]. Endocr J. 2011;58:613-24.

16. Del Rosso A, Cerinic MM, De Giorgio F, Minari C, Rotella CM, Seghier G. Rheumatological manifestations in diabetes mellitus. Curr Diabetes Rev. 2006;2:455-66

17. Watkinson S, Seewoodhary R. Ocular complications associated with diabetes mellitus. Nurs Stand. 2008;22:51-7. quiz 58,60

18. Higgins T. HbA1c for screening and diagnosis of diabetes mellitus Endocrine. 2013;43:266-73.

19. Sgolastra F, Severino M, Pietropaoli D, Gatto R, Monaco A. Effectiveness of periodontal treatment to improve metabolic control in patients with chronic periodontitis and type 2 diabetes: a meta-analysis of randomized clinical trials. J Periodontol. 2013;84:958-73.

20. Corbella S, Francetti L, Taschieri S, De Siena F, Fabbro MD. Effect of periodontal treatment on glycemic control of patients with diabetes: A systematic review and meta-analysis. J Diabetes Investig. 2013;4:502-9.

21. Engebretson $\mathrm{S}$, Kocher T. Evidence that periodontal treatment improves diabetes outcomes: a systematic review and meta-analysis. J Periodontol. 2013;84:S153-69.

22. Liew AK, Punnanithinont N, Lee YC, Yang J. Effect of non-surgical periodontal treatment on $\mathrm{HbA1c}$ : a meta-analysis of randomized controlled trials. Aust Dent J. 2013;58:350-7.

23. Cochrane Collaboration. Cochrane Handbook for Systematic Reviews of Interventions Version 5.1.0 [updated March 2011].=URL: http://www.cochrane-handbook.org. Accessed April 2012.

24. Teeuw WJ, Gerdes VE, Loos BG. Effect of periodontal treatment on glycemic control of diabetic patients: a systematic review and meta-analysis. Diabetes Care. 2010;33:421-7.

25. Kiran M, Arpak N, Unsal E, Erdogan MF. The effect of improved periodontal health on metabolic control in type 2 diabetes mellitus. J Clin Periodontol. 2005;32:266-72.

26. Chen L, Luo G, Xuan D, Wei B, Liu F, Li J, et al. Effects of non-surgical periodontal treatment on clinical response, serum inflammatory parameters, 
and metabolic control in patients with type 2 diabetes: a randomized study. J Periodontol. 2012:83:435-43.

27. Koromantzos PA, Makrilakis K, Dereka X, Offenbacher S, Katsilambros N, Vrotsos IA, et al. Effect of non-surgical periodontal therapy on C-reactive protein, oxidative stress, and matrix metalloproteinase (MMP)-9 and MMP-2 levels in patients with type 2 diabetes: a randomized controlled study. J Periodontol. 2012;83:3-10.

28. Moeintaghavi A, Arab HR, Bozorgnia Y, Kianoush K, Alizadeh M. Non-surgical periodontal therapy affects metabolic control in diabetics: a randomized controlled clinical trial. Aust Dent J. 2012;57:31-7.

29. Singh S, Kumar $V$, Kumar S, Subbappa A. The effect of periodontal therapy on the improvement of glycemic control in patients with type 2 diabetes mellitus: a randomized controlled clinical trial. Int J Diabetes Dev Ctries. 2008;28:38-44.

30. Zhang HH, Li CZ, Shang SH, Luo ZX. Scaling and root planing with enhanced root planing on healthcare for type 2 diabetes mellitus: a randomized controlled clinical trial. J Dent Sci. 2013:8:272-80.

31. Engebretson SP, Hyman LG, Michalowicz BS, Schoenfeld ER, Gelato MC, Hou W, et al. The effect of nonsurgical periodontal therapy on hemoglobin A1c levels in persons with type 2 diabetes and chronic periodontitis: a randomized clinical trial. JAMA. 2013;310:2523-32.

32. Gay IC, Tran DT, Cavender AC, Weltman R, Chang J, et al. The effect of periodontal therapy on glycaemic control in a Hispanic population with type 2 diabetes: a randomized controlled trial. J Clin Periodontol. 2014;41(7):673-80.

33. Raman RP, Taiyeb-Ali TB, Chan SP, Chinna K, Vaithilingam RD. Effect of nonsurgical periodontal therapy verses oral hygiene instructions on type 2 diabetes subjects with chronic periodontitis: a randomised clinical trial. BMC Oral Health. 2014;14:79.

34. Santos Tunes R, Foss-Freitas MC, Nogueira-Filho GR. Impact of periodontitis on the diabetes-related inflammatory status. J Can Dent Assoc. 2010;76:a35.

35. Lakschevitz F, Aboodi G, Tenenbaum H, Glogauer M. Diabetes and periodontal diseases: interplay and links. Curr Diabetes Rev. 2011;7:433-9.

36. Calle MC. Fernandez ML (2012) Inflammation and type 2 diabetes. Diabetes Metab. 2012;38:183-91

37. Rissanen A, Howard CP, Botha J, Thuren T. Effect of anti-IL-1 beta antibody (canakinumab) on insulin secretion rates in impaired glucose tolerance or type 2 diabetes: results of a randomized, placebo-controlled trial. Diabetes Obes Metab. 2012;14(12):1088-96.

38. Ridker PM, Howard CP, Walter V, Everett B, Libby P, Hensen J, et al. Effects of interleukin-1 beta inhibition with canakinumab on hemoglobin A1c, lipids, C-reactive protein, interleukin-6, and fibrinogen: a phase $\mathrm{llb}$ randomized, placebo-controlled trial. Circulation. 2012;126:2739-48.

39. Sloan-Lancaster J, Abu-Raddad E, Polzer J, Miller JW, Scherer JC, De Gaetano A, et al. Double-blind, randomized study evaluating the glycemic and anti-inflammatory effects of subcutaneous LY2189102, a neutralizing IL-1 beta antibody, in patients with type 2 diabetes. Diabetes Care. 2013;36:2239-46.

40. Goldfine AB, Conlin PR, Halperin F, Koska J, Permana P, Schwenke D, et al. A randomised trial of salsalate for insulin resistance and cardiovascular risk factors in persons with abnormal glucose tolerance. Diabetologia. 2013;56:714-23.

\section{Submit your next manuscript to BioMed Central and take full advantage of:}

- Convenient online submission

- Thorough peer review

- No space constraints or color figure charges

- Immediate publication on acceptance

- Inclusion in PubMed, CAS, Scopus and Google Scholar

- Research which is freely available for redistribution 